Int. J. Electrochem. Sci., 15 (2020) 1338 - 1346

\title{
Performance and Transport Characteristics of Solid Oxide Fuel Cells with Counter Flow Arrangement
}

\author{
Shian $\mathrm{Li}^{1}$, Rongqiang Wei ${ }^{1}$, Hao Wang ${ }^{1}$, Yuanxin $Q i^{2}$, Guogang Yang ${ }^{1, *}$, Qiuwan Shen ${ }^{1, *}$ \\ ${ }^{1}$ Marine Engineering College, Dalian Maritime University, Dalian, China; \\ ${ }^{2}$ Department of Energy Sciences, Lund University, Lund, Sweden; \\ *E-mail:yanggg@dlmu.edu.cn and shenqiuwan@dlmu.edu.cn
}

doi: $10.20964 / 2020.02 .32$

Received: 6 October 2019 / Accepted: 26 November 2019 / Published: 31 December 2019

In this study, a two-dimensional model including the governing equations of mass, momentum, species, energy and charge, is developed and then applied to investigate the performance and multiphysics transport processes of solid oxide fuel cells with counter-flow arrangement. The current density and power density are calculated and presented, and the distributions of species and temperature are also analyzed. In addition, temperature distributions of fuel cells with varying operating temperature, anode inlet flow velocity and cathode inlet flow velocity are demonstrated. The results show that the temperature gradient increases with increasing operating temperature. And the local temperature decreases with increasing inlet flow velocities, especially the increasing cathode inlet flow velocity.

Keywords: Solid oxide fuel cells, Transport phenomena, Counter flow, Temperature gradient

\section{FULL TEXT}

(C) 2020 The Authors. Published by ESG (www.electrochemsci.org). This article is an open access article distributed under the terms and conditions of the Creative Commons Attribution license (http://creativecommons.org/licenses/by/4.0/). 